\title{
Zmijewski dan Springate : Analisis Diskriminan dalam Memprediksi Financial Distress
}

\author{
Munawarah* \\ Fakultas Ekonomi, Universitas Prima Indonesia, munawarah1710@gmail.com, Medan, Indonesia
}

\section{ARTICLE INFO}

\section{Article history:}

Received 00 Maret 2018

Received in Revised 00 April 2018

Accepted 00 Juni 2018

\section{Keywords:}

Zmijewski, Springate ,Financial

Distress, $X$-score, dan $S$-score

\section{A B S T R A C T}

This study aims to analyze the differences between Zmijewski's model and Springate's model in predicting bankruptcy (financial distress) in property and real estate companies listed on the Indonesia Stock Exchange. The object of this research is companies registered in the property and real estate sectors starting from 2011-2015. With a total population of 47 companies. The sampling technique was taken through purposive sampling obtained by the number of samples as many as 35 companies. The variable used in this study is to take the cut-off value presented in the Zmijewski model (X-score) and the Springate model (S-Score). This study uses a descriptive approach with types of secondary data sourced from annual financial reports from 2011-2015. The results show that in Zmijewski's model there are several companies that have the potential to experience bankruptcy, namely 15 companies in 2011, 13 companies in 2012 and 2013, 17 companies in 2014, and 12 companies in 2015. Whereas through the Springate model found several companies that have the potential bankruptcy, namely 24 companies in 2011, 20 companies in 2012, 17 companies in 2013, 14 companies in 2014, and 19 companies in 2015.

Penelitian ini bertujuan untuk menganalisis perbedaan model Zmijewski dengan model Springate dalam memprediksi financial distress pada perusahaan property dan real estate yang terdaftar di Bursa Efek Indonesia. Objek penelitian merupakan perusahaan sektor property dan real estate dari tahun 2011-2015. Total populasi 47 perusahaan. Sampel sebesar 35 perusahaan diambil dengan teknik purposive. Total pengamatan 175 perusahaan. Variabel pada penelitian ini adalah mengambil nilai cut-off yang tersaji pada model Zmijewski (X-score) dan model Springate (S-Score). Penelitian menggunakan pendekatan deskriptif dengan jenis data sekunder yang bersumber dari laporan keuangan tahunan dari 2011-2015. Hasil menunjukkan pada model Zmijewski ada beberapa perusahaan yang berpotensi mengalami kebangkrutan yaitu 15 perusahaan pada tahun 2011, 13 perusahaan pada tahun 2012 dan 2013, 17 perusahaan pada tahun 2014, dan 12 perusahaan pada tahun 2015. Sedangkan melalui model Springate ditemukan beberapa perusahaan yang berpotensi mengalami kebangkrutan, yaitu 24 perusahaan pada tahun 2011, 20 perusahaan pada tahun 2012, 17 perusahaan pada tahun 2013, 14 perusahaan pada tahun 2014, dan 19 perusahaan pada tahun 2015.

AKUISISI : Jurnal Akuntansi

Website : http://www.fe.ummetro.ac.id/ejournal/index.php/JA 


\section{PENDAHULUAN}

Pada prinsipnya, perusahaan berdiri karena adanya tujuan bersama untuk memperoleh laba sebesar-besarnya. Laba sebagai target utama yang sering disebut sebagai istilah triple bottom line dapat dicapai melalui proses yang efektif dan efisien, seperti memperoleh dana yang cukup yang bisa berasal dari luar perusahaan, baik berupa pinjaman dengan bunga rendah, memiliki jangka waktu lama, dan dengan persyaratan lunak yang tidak memberatkan perusahaan. Suatu perusahaan dikatakan well established dan memiliki performa baik jika dilihat dari dua rasio keuangan utama yaitu sisi profitabilitas, dan likuiditasnya. Indonesia sedang gencar-gencarnya menuju perbaikan infrastruktur yang diharapkan dapat meningkatkan perekonomian negara. Infrastruktur vital yang banyak dibangun seperti jalan tol, atau under pass tentu memberikan dampak besar bagi sektor property dan real estate terutama pada bidang perumahan mewah dan real estate. Wibowo (2011) mengatakan infrastruktur yang baik akan merangsang investor untuk berinvestasi di bidang ini, karena dengan infrastruktur yang baik diharapkan mampu menjadikan real estate bisa diterima masyarakat, sehingga baik pengembang, investor, maupun masyarakat dapat merasakan manfaat dari infrastruktur yang berkualitas. Selain itu semakin meningkatnya jumlah penduduk namun tidak didukung dengan ketersediaan lahan, membuat semakin menjamurnya bisnis ini untuk memenuhi kebutuhan tempat tinggal masyarakat. Tercatat dari tahun 2012 hingga pertengahan tahun 2013 sektor Properti Indonesia bertumbuh cepat (dari 45 perusahaan properti yang terdaftar di Bursa Efek Indonesia pada tahun 2012, 26 perusahaan mencatat pertumbuhan laba bersih lebih dari 50\%) dan, jelas, harga properti Indonesia meningkat sejalan dengan itu (pada umumnya harga properti residensial bertumbuh hampir 30\% per tahun antara 2011 dan 2013). Naiknya sektor ini tidak lepas dari faktor pertumbuhan ekspansi perekonomian yang kuat dilihat dari pertumbuhan PDB per kapita Indonesia pada level $+6 \%$ dan daya beli masyarakat menguat. Selain itu komposisi demografi dengan jumlah populasi mencapai 250 juta jiwa, dengan refleksi segmen kelas menengah dengan usia muda dibawah 30 tahun tiap tahunnya bertambah, sehingga dapat dikatakan kemampuan masyarakat Indonesia dalam membeli property cukup tinggi. Namun kondisi ini tidak berlangsung lama, karena inflasi tinggi akibat naiknya harga bahan bakar bersubsidi, dan terjadi pengetatan kebijakan moneter Amerika Serikat menyebabkan pelemahan nilai tukar rupiah sejak pertengahan tahun 2013. Selain itu tahun 2014 sebagai tahun politik menyebabkan kondisi perekonomian menjadi tidak jelas, karenanya banyak pengembang (developer) yang cenderung menunda proyek-proyek baru akibat kekhawatirannya mengenai stabilitas politik Indonesia yang rentan sehingga menyebabkan penurunan pasar property di Indonesia (www.indonesia-investments.com).

Dengan kondisi negara Indonesia yang cenderung fluktuatif menyebabkan industri Property dan real estate juga mengalami fase naik turun. Adakalanya perusahaan yang telah lama berdiri dan menjalankan kegiatan operasionalnya terpaksa mengalami likuidasi karena mengalami krisis keuangan. Sebagai negara yang sedang berkembang, yang sangat rentan terhadap gejolak politik dan ekonomi, tentu akan berdampak pada perusahaan. Bagi perusahaan yang mampu menghadapi kondisi ini akan tetap bertahan dan bahkan terus mengembangkan usahanya. Sebaliknya bagi perusahaan yang tidak mampu mengantisipasi gejolak ekonomi, akan berujung pada kebangkrutan. Hal ini juga didukung dengan keputusan delisting seperti PT.Pancawirawakti, Tbk pada tahun 2013 karena tidak mampu membayar kewajiban biaya pencatatan, dan kinerja keuangannya terus menurun, PT. New Century Development Tbk pada tahun 2011, dan PT.Surya Inti Permata Tbk yang didelisting pada tahun 2012. Delisting dapat menunjukkan bahwa perusahaan tersebut tidak memenuhi kriteria sebagai saham yang likuid di Bursa dan ini menggambarkan bahwa perusahaan mengalami stress keuangan (financial distress) yang menyebabkan kebangkrutan, karena adanya kerugian operasional sehingga berdampak pada pembagian dividen kepada para pemegang saham. Bursa efek akan mengeluarkan perusahaan tersebut karena tidak menunjukkan performa yang baik, dan dapat membuat investor tidak akan mau berinvestasi di efek yang dikeluarkan perusahaan tersebut.

Untuk mengantisipasi terjadinya kebangkrutan perusahaan di masa mendatang, maka perlu dilakukan analisis terhadap rasio-rasio keuangan perusahaan. Analisis kondisi kebangkrutan ini dikenal dengan istilah financial distress analysis. Analisis ini perlu dilakukan untuk mengetahui keadaan kesulitan keuangan perusahaan sejak dini sehingga dapat dilakukan antisipasi kondisi yang mengarah kepada kebangkrutan. Ada banyak model yang digunakan untuk memprediksi financial distress (kebangkrutan) yang telah dilakukan oleh para ahli diantaranya Model Zmijewski dan Model Springate. Model Zmijewski merupakan model prediksi dari hasil riset Zmijewski (1984) selama 20 tahun. Model ini memperhitungkan rasio keuangan Profitabilitas yang diukur melalui return on Asset (ROA), rasio Solvabilitas yang diukur melalui Debt to Asset Ratio (DAR), dan rasio Likuiditas yang diukur melalui Current Ratio (CR). Zmijewski melakukan prediksi dengan sampel 75 perusahaan bangkrut dan 73 perusahaan sehat selama tahun 1972 sampai tahun 1978, indicator F-Test terhadap rasio kelompok rate of return, liquidity, leverage turnover, fixed payment coverage, trens, firm size, dan stock return volatility, menunjukkan perbedaan signifikan antara perusahaan yang sehat dan tidak sehat. Rumus Model ini adalah sebagai berikut

Keterangan :

$$
X=-4,3-4,5 X_{1}+5,72 X_{2}-0,004 X_{3}
$$

$\mathrm{X} 1=$ Return on Asset $(R O A)$

$\mathrm{X}_{2}=$ Debt to Asset Ratio $(D A R)$

$\mathrm{X}_{3}=$ Current Ratio

Model ini menetapkan cut off dengan skor jika X melebihi 0 maka dapat dinyatakan sebuah perusahaan diprediksi berpotensi mengalami kebangkrutan. Dan jika nilai X skor nya kurang dari 0 maka perusahaan diprediksi tidak berpotensi untuk mengalami kebangkrutan. (Wulandary dan Nur, 2014).

Sementara model Springate merupakan model prediksi kebangkrutan yang diteliti tahun 1978 dan merupakan pengembangan dari model Altman dengan menggunakan Multiple Diskriminant Analysis (MDA). Model ini menggunakan 4 rasio keuangan untuk menentukan kriteria perusahaan apakah masuk dalam kategori perusahaan yang sehat atau justru yang berpotensi mengalami kebangkrutan. Rasio keuangan yang digunakan berasal dari rasio aktivitas yang terlihat dari rasio perputaran modal kerja, rasio perputaran total aset, rasio rentabilitas ekonomi, dan rasio laba sebelum pajak terhadap utang lancar. Model Springate ini dapat digunakan untuk memprediksi kebangkrutan dengan nilai keakurat 92,5\%. Model ini dapat digunakan dengan persamaan sebagai berikut :

$$
S=1,03 A+3,07 B+0,66 C+0,4 D
$$

Keterangan : 
Nilai cut-off yang berlaku untuk model ini adalah 0,862. Jika Nilai S lebih kecil dari 0,862 menunjukkan bahwa perusahaan tersebut diprediksi akan mengalami kebangkrutan. Sebaliknya jika nilai S-Score lebih besar 0,862 maka perusahaan dikategorikan sehat. Maka berdasarkan uraian diatas maka rumusan masalah dalam penelitian ini adalah seberapa besar perbedaan keakuratan model Zmijewski dan model Springate dalam memprediksi financial distress perusahaan Property dan Real Estate di Bursa Efek Indonesia.

\section{METODE PENELITIAN}

\subsection{Data dan Metode pengumpulan data}

Penelitian ini menggunakan jenis data sekunder yang bersumber dari laporan keuangan tahunan perusahaan Property dan Real Estate yang terdaftar di Bursa Efek Indonesia tahun 2011-2015. Metode pengumpulan data yang digunakan oleh peneliti adalah metode dokumentasi, yaitu dengan mencari dan mengumpulkan data sekunder laporan tahunan untuk melihat rasio keuangan pada model Zmijewski dan model Springate. Dalam penelitian ini, yang menjadi subjek pengumpulan data yaitu perusahaan property dan real estate yang terdaftar di Bursa Efek Indonesia periode 2011 - 2015.

\subsection{Teknik Analisis Data}

Penelitian menggunakan analisis deskriptif untuk melihat deskripsi atau gambaran suatu data yang dilihat dari nilai mean (rata-rata), standar deviasi, nilai maksimum dan minimum pada kedua model prediksi kebangkrutan yaitu model Zmijewski dan Springate. Statistik deskriptif dapat dijelaskan melalui program SPSS.

Selain melalui analisa deskriptif, penelitian ini juga memiliki tahapan-tahapan dalam menganalisis adanya indikasi kebangkrutan menggunakan kedua model prediksi kebangkrutan yaitu Model Zmijewski dan Model Springate yaitu menghitung rasio keuangan selama kurun waktu 5 tahun pengamatan dari 2011-2015 sebagai berikut :

a. Pada Model Zmijewski akan dihitung rasio keuangan profitabilitas yaitu rasio laba bersih terhadap total aset, rasio solvabilitas yaitu rasio utang terhadap total aset, dan rasio likuiditas yaitu rasio lancar melalui perbandingan antara aset lancar dan utang lancar. Sementara pada model Springate akan dihitung rasio keuangan modal kerja terhadap total aset, rasio laba sebelum bunga dan pajak terhadap total aset, rasio laba sebelum pajak terhadap total utang lancar, dan rasio penjualan terhadap total aset.

b. Berdasarkan rasio tersebut, maka dilakukan perhitungan yang menggabungkan rasio-rasio keuangan ke dalam formula. Untuk model Zmijewski dapat digunakan rumus :

$$
\mathrm{X}=-4,3-4,5 \mathrm{X} 1+5,72 \mathrm{X} 2-0,004 \mathrm{X} 3 .
$$

Dimana :

$\mathrm{X}_{1}=$ Return on Asset $(\mathrm{ROA})$

$\mathrm{X}_{2}=$ Debt to Asset Ratio (DAR)

$\mathrm{X}_{3}=$ Current Ratio

Sedangkan pada model Springate rasio-rasio keuangan dapat dimasukkan kedalam rumus:

$$
\mathrm{S}=1,03 \mathrm{~A}+3,07 \mathrm{~B}+0,66 \mathrm{C}+0,4 \mathrm{D}
$$

Dimana :

A $=$ Working Capital to Total Asset

$\mathrm{B}=$ EBIT to Total Asset

$\mathrm{C}=$ EBT to Current Liabilities

$\mathrm{D}=$ Sales to Total Asset

c. Dari masing-masing persamaan tersebut dilakukan interpretasi hasil berdasarkan nilai cut-off yang telah ditetapkan untuk penentuan status sehat tidaknya perusahaan. Pada model Zmijewski jika nilai X > 0 perusahaan diprediksi mengalami kebangkrutan (Financial Distress), sebaliknya jika $\mathrm{X}<0$ maka perusahaan dapat dikatakan dalam kondisi sehat. Sementara pada model Springate nilai cut-off untuk penentuan status perusahaan dilihat pada nilai S jika $<0,862$ perusahaan dikategorikan sedang dalam kondisi tidak sehat atau mengalami kebangkrutan (financial distress), sebaliknya jika $S>0,862$ maka perusahaan berada pada kondisi sehat.

\subsection{Populasi dan Sampel}

Populasi dalam penelitian ini adalah perusahaan-perusahaan yang tergabung dalam sub sektor property dan real estate yang listing (terdaftar) di Bursa Efek Indonesia tahun 2011-2015 sebanyak 47 perusahaan termasuk didalamnya perusahaan yang didelisting dari tahun 2011-2015, dan perusahaan yang baru IPO maupun reslisting dari tahun 2011-2015. Teknik pengambilan sampel melalui purposive sampling dengan menetapkan kriteria : 1 . Perusahaan Property dan Real Estate yang terdaftar secara berturut-turut di Bursa Efek mulai tahun 2011-2015. 2. Perusahaan Property dan Real Estate yang menyajikan laporan keuangan tahunan yang sudah diaudit berturut-turut tahun 2011-2015. Diperoleh sampel yang lolos kriteria sebanyak 175 perusahaan. 
2.4 Identifikasi dan Definisi Operasional Variabel Penelitian

Adapun variabel yang diukur dalam model Zmijewski dan Model Springate adalah sebagai berikut :

Tabel 1. Identifikasi dan Defenisi Operasional Variabel

\begin{tabular}{|c|c|c|c|}
\hline Variabel & Definisi Variabel & Indikator Variabel & Skala Pengukuran \\
\hline Profitabilitas & $\begin{array}{l}\text { Profitabilitas diukur melalui perbandingan antara laba bersih } \\
\text { setelah pajak dibagi dengan total aktiva perusahaan. }\end{array}$ & $R O A=\frac{\text { Earning After Tax }}{\text { Total Asset }}$ & Rasio \\
\hline Solvabilitas & $\begin{array}{l}\text { Solvabilitas diukur melalui kemampuan perusahaan dalam } \\
\text { melunasi seluruh utang-utangnya. Diukur dengan } \\
\text { membandingkan total utang dengan total aktiva perusahaan. }\end{array}$ & DAR $=\frac{\text { Total Debt }}{\text { Total Asset }}$ & Rasio \\
\hline Likuiditas & $\begin{array}{l}\text { Likuiditas diukur melalui kemampuan perusahaan dalam } \\
\text { menyelesaikan kewajiban jangka pendeknya tepat waktu } \\
\text { atau sebelum jatuh tempo. }\end{array}$ & Current Ratio $=\frac{\text { Current } \text { Asset }}{\text { Current liabilities }}$ & Rasio \\
\hline Aktivitas & $\begin{array}{l}\text { Rasio ini diukur untuk mengetahui seberapa efektif } \\
\text { manajemen dalam menggunakan aktiva yang dimiliki dalam } \\
\text { kegiatan perusahaan. }\end{array}$ & $\begin{array}{c}\text { Working Capital turnover }= \\
\frac{\text { Working Capital }}{\text { Total Asset }}\end{array}$ & Rasio \\
\hline Aktivitas & $\begin{array}{l}\text { Rasio ini diukur untuk mengetahui seberapa efektif } \\
\text { manajemen dalam menggunakan aktiva yang dimiliki dalam } \\
\text { kegiatan perusahaan. }\end{array}$ & Total Asset turnover $=\frac{\text { Sales }}{\text { Total Asset }}$ & Rasio \\
\hline $\begin{array}{l}\text { Rentabilitas } \\
\text { Ekonomi }\end{array}$ & $\begin{array}{l}\text { Rasio ini diukur untuk mengetahui seberapa efektif } \\
\text { pengelolaan aktiva yang dapat menghasilkan laba } \\
\text { perusahaan }\end{array}$ & Rentabilitas Ekonomi $=\frac{E B I T}{\text { Total Asset }}$ & Rasio \\
\hline Likuiditas & $\begin{array}{l}\text { Likuiditas diukur melalui kemampuan perusahaan dalam } \\
\text { menyelesaikan kewajiban jangka pendeknya tepat waktu } \\
\text { atau sebelum jatuh tempo. }\end{array}$ & EBTCL $=\frac{E B I T}{\text { Current Liabilities }}$ & Rasio \\
\hline $\begin{array}{c}\text { Financial } \\
\text { distress }\end{array}$ & $\begin{array}{l}\text { Tahap penurunan kondisi keuangan yang terjadi sebelum } \\
\text { terjadinya kebangkrutan }\end{array}$ & 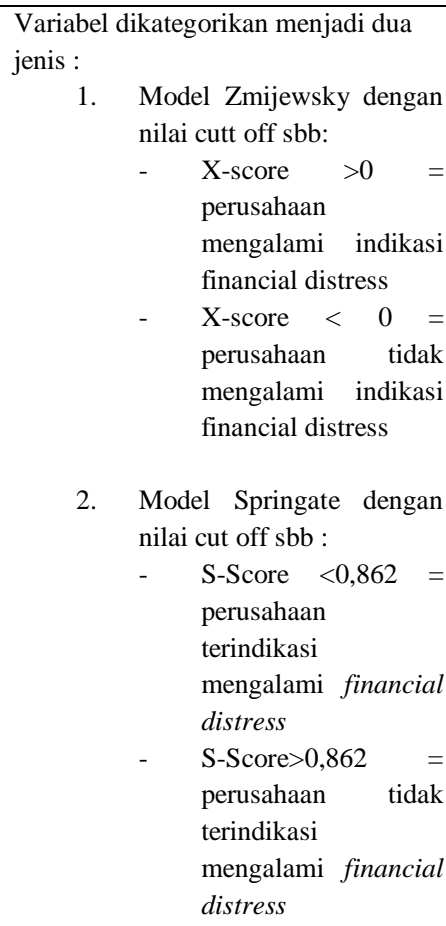 & Dummy \\
\hline
\end{tabular}




\section{HASIL DAN PEMBAHASAN}

\subsection{Statistik Deskriptif}

Tabel 2 Statistik Deskriptif model Zmijewski (X-Score) dan model Springate (S-Score)

\begin{tabular}{|l|r|r|r|r|r|}
\hline & \multicolumn{1}{|c|}{$\mathrm{N}$} & Minimum & Maximum & \multicolumn{1}{c|}{ Mean } & Std. Deviation \\
\hline X_Score & 175 & -4.6620 & 11.6150 & -.26715 & 2.9643 \\
S_Score & 175 & -3.4587 & 4.3125 & .87827 & .7897 \\
Valid N (listwise) & 175 & & & & \\
\multicolumn{2}{|l}{ Sumber : Data Diolah (2018) }
\end{tabular}

Hasil statistik deskriptif model Zmijewski melalui X-Score dari tahun 2011-2015 menunjukkan nilai terendah sebesar -4,6620 yaitu nilai PT. Greenwood Sejahtera Tbk pada tahun 2015, dan nilai tertinggi sebesar 11,6150 yaitu nilai dari PT. Goa Makassar Tourism Development Tbk pada tahun 2012. Nilai rata-rata sebesar -0,26715 dengan standar deviasi sebesar 2,9643. Sedangkan dengan model Springate melalui S-Score dari tahun 2011 sampai 2015 menunjukkan nilai terendah sebesar -3,4587 yang merupakan nilai PT. Rista Bintang Mahkota Sejati Tbk pada tahun 2011, dan nilai tertinggi sebesar 4,3125 merupakan nilai dari perusahaan PT. Greenwood Sejahtera Tbk pada tahun 2015, nilai rata-rata sebesar 0,87827 dan standar deviasi sebesar 0,7897 .

\subsection{Pembahasan Model Prediksi Kebangkrutan}

Dari sampel yang diperoleh sebanyak 135 perusahaan selama 5 periode yaitu 2011 - 2015 sehingga terdapat 105 sampel pada perusahaan property dan real estate dalam kondisi sehat dan tidak terindikasi mengalami kebangkrutan sebaliknya 70 perusahaan property dan real estate dalam kondisi tidak sehat dan terindikasi mengalami kebangkrutan. Hasil analisis dapat dijelaskan melalui tabel di bawah ini :

Tabel 3 Hasil Prediksi Kebangkrutan Model Zmijewsky dan Springate Periode 2011-2015

\begin{tabular}{|c|c|c|c|c|}
\hline \multirow{2}{*}{ Tahun } & \multicolumn{2}{|c|}{ Model Zmijewsky } & \multicolumn{2}{c|}{ Model Springate } \\
\cline { 2 - 5 } & Tidak Bangkrut & Bangkrut & Tidak Bangkrut & Bangkrut \\
\hline 2011 & 20 & 15 & 11 & 24 \\
\hline 2012 & 22 & 13 & 15 & 20 \\
\hline 2013 & 22 & 13 & 18 & 17 \\
\hline 2014 & 18 & 17 & 21 & 14 \\
\hline 2015 & 23 & 12 & 15 & 20 \\
\hline
\end{tabular}

Sumber : Data Diolah (2018)

Berdasarkan analisis tersebut, dapat diperoleh kesimpulan bahwa perusahaan yang berada dalam kondisi tidak sehat dan diprediksi mengalami kebangkrutan dengan menggunakan model Zmijewsky periode 2011 sampai 2015 sebanyak $40 \%$ yaitu 70 perusahaan, dan perusahaan yang berada dalam kondisi sehat dan tidak terindikasi mengalami kebangkrutan sebesar 60\% yaitu 105 perusahaan dari total pengamatan sebanyak 175 sampel perusahaan.

Model Zmijewski menggunakan tiga rasio keuangan.Rasio yang pertama yaitu ROA. ROA yaitu perbandingan antara laba setelah pajak dengan jumlah aset (Cahyaningrum dan Haryanto, 2012). Rasio ini akan menunjukkan tingkat kemampuan perusahaan dalam menghasilkan laba dari rata-rata asetnya. Semakin tinggi ROA maka kondisi kesehatan perusahaan semakin baik, dan kemungkinan mengalami kondisi financial distress akan semakin kecil. Rasio kedua yaitu debt ratio. Rasio ini akan mengukur tingkat persentase aktiva yang dibiayai oleh hutang. Rasio yang terakhir yaitu current ratio. Rasio ini digunakan untuk mengukur likuiditas perusahaan. Likuiditas merupakan kemampuan perusahaan dalam memenuhi kewajiban jangka pendeknya. Semakin tinggi kemampuan perusahaan dalam memenuhi kewajibanya, maka perusahaan tersebut dikatakan sebagai perusahaan yang sehat.

Hasil penelitian ini mendukung penelitian dari Casterella, dkk., (2002) yang mengungkapkan kelemahan penggunaan model Zmijewski sebagai model prediksi kebangkrutan. Kusumawardani (2015) menilai bahwa model Zmijewski memiliki keakuratan tertinggi dalam memprediksi delisting atau tidaknya suatu perusahaan di BEI dalam kurun waktu satu sampai tiga tahun dari hasil prediksi. Fatmawati (2012) memperlihatkan bahwa model Zmijewski merupakan predictor delisting terakurat. Penelitian Pambekti (2014) menyimpulkan bahwa model Zmijewski adalah model prediksi financial distress yang paling tepat digunakan untuk memprediksi financial distress perusahaan di masa yang akan datang.

Model prediksi S-Score Springate memiliki tingkat akurasi paling tinggi. Hal ini mengindikasikan bahwa rasio keuangan yang digunakan oleh Springate mampu memprediksi 80 perusahaan property dan real estate atau sebesar 45,8\% dalam kondisi sehat dan tidak terindikasi mengalami kebangkrutan, sebaliknya 95 perusahaan property dan real estate atau sebesar $54,2 \%$ dalam kondisi tidak sehat dan terindikasi mengalami kebangkrutan. Hal ini dapat disebabkan karena adanya perbedaan penggunaan rasio keuangan dari masing-masing model selain juga nilai cut off yang masing-masing berbeda pada setiap model. 


\begin{tabular}{|c|c|c|c|}
\hline \multirow{2}{*}{ Tahun } & \multicolumn{3}{|c|}{ Hasil Perbandingan Status Kebangkrutan } \\
\cline { 2 - 4 } & Beda & Tidak Beda & Total \\
\hline 2011 & 17 & 18 & 35 \\
\hline 2012 & 15 & 20 & 35 \\
\hline 2013 & 16 & 19 & 35 \\
\hline 2014 & 13 & 22 & 35 \\
\hline 2015 & 14 & 21 & 35 \\
\hline Total & $\mathbf{7 5}$ & $\mathbf{1 0 0}$ & $\mathbf{1 7 5}$ \\
\hline
\end{tabular}

Hasil perbandingan status kebangkrutan melalui dua model yaitu Zmijewsky dan Springate menunjukkan adanya perbedaan penentuan status bangkrut tidaknya suatu perusahaan. Terdapat perbedaan sebesar 42,9\% dari 175 pengamatan sampel penelitian mulai dari tahun 2011 sampai 2015. Sebaliknya ditemukan ada sebesar $57,1 \%$ persamaan antara kedua model dalam menentukan status kebangkrutan.

Tahun 2011 nilai terendah dari penentuan status kebangkrutan model Zmijewsky sebesar -3,566 merupakan nilai dari PT. Sentul City, Tbk, sedangkan model Springate sebesar -3,459 merupakan nilai dari PT. Rista Bintang Mahkota Sejati Tbk. Nilai tertinggi pada model Zmijewski sebesar 8,355 yang merupakan nilai dari PT. Summarecon Agung Tbk, sedangkan pada model Springate ada pada PT. Dadanayasa Arihtama Tbk dengan nilai 3,951. Tahun 2012 nilai terendah model Zmijewski ada pada PT. Rista Bintang Mahkota Sejati Tbk dengan nilai -3,982, sedangkan model Springate sebesar -0,183 yang merupakan nilai PT. Bukit Darmo Property Tbk. Dan untuk nilai tertinggi sebesar 11,65 yaitu pada PT. Goa Makassar Tourism Development Tbk dengan model Zmijewski, dan pada model Springate nilai tertinggi sebesar 3,130 pada PT. Dadanayasa Arihtama Tbk. Pada tahun 2013, nilai tertinggi pada model Zmijewski sebesar 6,161 yaitu PT.Summarecon Agung Tbk dan nilai terendah -4,385 pada PT.Greenwood Sejahtera Tbk. Sedangkan pada model Springate nilai tertinggi 3,988 ada pada PT. Dadanayasa Arihtama Tbk, dan nilai terendah -0,280 pada PT. Bukit Darmo Property Tbk. Pada tahun 2014 nilai tertinggi pada model Zmijewsky sebesar 1,448 pada PT.Indonesia Prima Property Tbk, dan nilai terendah sebesar 0,219 pada PT.Sentul City Tbk, sedangkan model Springate nilai tertinggi 5,760 yaitu PT Agung Podomoro Land, Tbk dan nilai terendah sebesar -4,321 pada PT.Greenwood Sejahtera Tbk. Dan pada tahun 2015 model Zmijewsky menunjukkan nilai tertinggi PT.Cowell Development Tbk sebesar 7,406, dan nilai terendah -4,662 pada PT. Greenwood Sejahtera Tbk. Sedangkan model Springate nilai tertinggi juga terdapat pada PT.Greenwood Sejahtera Tbk sebesar 4,313 dan nilai terendah ada pada PT. Indonesia Prima Property Tbk dengan nilai -0,058.

Adanya perbedaan hasil dari penggunaan model Zmijewsky dan model Springate dapat disebabkan karena berbedanya rasio keuangan yang digunakan dari masing-masing metode. Model Zmijewsky lebih menekankan kepada perhitungan 3 rasio keuangan utama yaitu rasio keuangan profitabilitas, solvabilitas, dan likuiditas. Dimana perusahaan harus mampu menghasilkan laba untuk menyelesaikan kewajiban jangka pendek maupun jangka panjangnya. Sedangkan pada model Springate yang merupakan pengembangan model prediksi Altman menggunakan rasio aktivitas dan laba perusahaan. Model ini hanya fokus pada aktivitas perusahaan dalam menghasilkan pendapatan melalui produksi barang dan penjualan yang dihasilkan.

\subsection{Akurasi Model Prediksi Kebangkrutan untuk perusahaan Property dan Real Estate berlaba negatif periode 2011-2015}

Dalam menentukan status kesehatan suatu perusahaan juga dapat dilihat melalui perolehan laba. Perusahaan yang mengalami masalah keuangan tentunya akan sulit memperoleh laba, dapat terlihat tabel berikut ini :

Tabel 5 Akurasi Model Prediksi Kebangkrutan pada Perusahaan Property dan Real Estate berlaba Negatif periode 2011-2015

\begin{tabular}{|c|c|c|c|l|l|l|l|}
\hline NO & KODE & TAHUN & NET INCOME & $\begin{array}{c}\text { MODEL } \\
\text { ZMIJEWSKY }\end{array}$ & STATUS & $\begin{array}{c}\text { MODEL } \\
\text { SPRINGATE }\end{array}$ & STATUS \\
\hline 1 & BIPP & 2011 & $(20,202,268,389)$ & 5.463 & BANGKRUT & $(0.622)$ & BANGKRUT \\
\hline 2 & BIPP & 2012 & $(16,490,566,723)$ & 2.420 & BANGKRUT & $(0.155)$ & BANGKRUT \\
\hline 3 & BKDP & 2011 & $(20,783,965,972)$ & $(2.049)$ & $\begin{array}{c}\text { TIDAK } \\
\text { BANGKRUT }\end{array}$ & $(0.075)$ & BANGKRUT \\
\hline 4 & BKDP & 2012 & $(58,396,713,479)$ & $(1.820)$ & $\begin{array}{c}\text { TIDAK } \\
\text { BANGKRUT }\end{array}$ & $(0.183)$ & BANGKRUT \\
\hline 5 & BKDP & 2013 & $(59,138,577,168)$ & $(1.591)$ & $\begin{array}{c}\text { TIDAK } \\
\text { BANGKRUT }\end{array}$ & $(0.280)$ & BANGKRUT \\
\hline 6 & BKDP & 2015 & $(28,227,002,713)$ & $(1.977)$ & TIDAK & $(0.015)$ & BANGKRUT \\
\hline 7 & COWL & 2015 & & & BANGKRUT & & BANGKRUT \\
\hline
\end{tabular}




\begin{tabular}{|c|c|c|c|c|c|c|c|}
\hline & & & $(174,809,293,323)$ & 7.406 & & 0.040 & \\
\hline 8 & MTSM & 2014 & $(1,095,507,550)$ & (3.564) & $\begin{array}{c}\text { TIDAK } \\
\text { BANGKRUT }\end{array}$ & 0.730 & BANGKRUT \\
\hline 9 & MTSM & 2015 & $(4,678,222,844)$ & (3.304) & $\begin{array}{c}\text { TIDAK } \\
\text { BANGKRUT }\end{array}$ & 0.307 & BANGKRUT \\
\hline 10 & OMRE & 2013 & $(23,884,469,677)$ & (1.164) & $\begin{array}{c}\text { TIDAK } \\
\text { BANGKRUT }\end{array}$ & 0.093 & BANGKRUT \\
\hline 11 & OMRE & 2015 & $(20,881,731,189)$ & (3.012) & $\begin{array}{c}\text { TIDAK } \\
\text { BANGKRUT }\end{array}$ & $(0.058)$ & BANGKRUT \\
\hline 12 & RBMS & 2011 & $(23,884,469,677)$ & (3.430) & $\begin{array}{c}\text { TIDAK } \\
\text { BANGKRUT }\end{array}$ & (3.459) & BANGKRUT \\
\hline 13 & RBMS & 2013 & $(20,881,731,189)$ & $(2.526)$ & $\begin{array}{c}\text { TIDAK } \\
\text { BANGKRUT }\end{array}$ & 0.152 & BANGKRUT \\
\hline
\end{tabular}

Sumber : Data Diolah (2018)

Untuk menentukan keakuratan dari kedua model prediksi dapat diukur melalui perusahaan yang mengalami kerugian selama tahun 2011-2015. Dari model Zmijewski diperoleh 4 perusahaan yang dinyatakan sehat dan tidak berpotensi mengalami kebangkrutan padahal perusahaan tersebut mengalami kerugian, yaitu pada PT. Bukit Darmo Property Tbk tahun 2011,2012, 2013 dan 2015, PT. Metro Realty Tbk pada tahun 2014 dan 2015 , PT. Indonesia Prima Property tahun 2013 dan 2015, serta PT. Rista Bintang Mahkota Sejati Tbk pada tahun 2011 dan 2013. Sedangkan pada model Springate dapat dilihat bahwa semua perusahaan yang mengakami kerugian sudah tepat dipastikan terindikasi mengalami kebangkrutan. Ini membuktikan bahwa model Springate lebih akurat dalam menentukan status perusahaan. Sesuai dengan penelitian terdahulu yang menyatakan bahwa model Springate yang telah diteliti oleh Gordon L. Springate tahun 1978 ini mampu memprediksi kebangkrutan dengn nilai akurat mencapai 92,5\% (Puspitasari, 2014).

\section{KESIMPULAN}

Model Zmijewski melalui nilai X-score dapat memprediksi perusahaan Property dan Real Estate yang berada dalam kondisi tidak sehat atau terindikasi mengalami kebangkrutan ada sebanyak $40 \%$ mulai dari periode 2011 sampai 2015 . Sementara perusahaan yang berada dalam kondisi sehat ada sebanyak $60 \%$. Sedangkan Model Springate melalui nilai Z-score dapat memprediksi perusahaan Property dan Real Estate yang berada dalam kondisi tidak sehat atau terindikasi mengalami kebangkrutan sebanyak 54,2\% dan perusahaan yang berada dalam kondisi sehat sebanyak 45,8 \% mulai tahun 2011-2015. Dalam menentukan status kebangkrutan perusahaan terdapat perbedaan dari model Zmijewsky dan model Springate yaitu sebesar $42,9 \%$ dan $57,1 \%$ persamaan status antara kedua modeldari 175 pengamatan sampel penelitian mulai dari tahun 2011 sampai 2015. Dalam menentukan keakuratan masing-masing model dapat dlihat dari penentuan status kebangkrutan pada perusahaan yang mengalami kerugian. Model Zmijewski hanya mampu memberikan akurasi $23,1 \%$ perusahaan yang berpotensi bangkrut sedangkan $76,9 \%$ perusahaan lainnya tidak akurat. Sedangkan pada model Springate mampu prediksi $100 \%$ perusahaan yang mengalami kerugian pasti mengalami kebangkrutan. Maka dapat disimpulkan bahwa model Springate merupakan model prediksi yang paling tepat dan akurat untuk menentukan kondisi Financial distress perusahaan yang berada pada sektor Property dan Real estate tahun 2011-2015.

Peneliti selanjutnya diharapkan dapat menambah objek pengamatan baik dari sektor perusahaan maupun periode pengamatan, sehingga dapat menggambarkan informasi yang lebih akurat. Penelitian dapat menggunakan model prediksi lain seperti Model Grover, Fullmer Score, Altman, Ohlson dan lainnya sehingga dapat diperoleh model prediksi mana yang akurat. Pertumbuhan ekonomi, inflasi, harga saham dan lainnya juga dapat dijadikan bahan pertimbangan peneliti selanjutnya untuk memperoleh hasil prediksi yang lebih akurat.

\section{Daftar Pustaka}

Adriana, A.N.2012. Analisis Prediksi Kebangkrutan Menggunakan Metode Springate Pada Perusahaan Foods and Beverages yang Terdaftar di Bursa Efek Indonesia periode 2006-2010. E-journal Repository Akuntansi Universitas Riau. 4(1) : 5-20.

Citrawati, E. Dan M.Gede.2014. Analisis kesulitan keuangan Altman, Springate,dan Zmijewski pada PT.Fast Food Indonesia, Tbk. E-Journal Fakultas Ekonomi Universitas Udayana.6 (3) : 379-389.

Cahyaningrum, N. H. dan A. M. Haryanto.2012. Analisis Manfaat Rasio Keuangandalam Memprediksi Pertumbuhan Laba(Studi Kasus: Perusahaan Manufaktur yangterdaftar di Bursa Efek Indonesia periode2005 sampai dengan 2010). DisertasiDoktoral, Universitas Diponegoro.

Fatmawati, M. 2012. Penggunaan The Zmijewski Model, The Altman Model, dan The Springate Model Sebagai Prediktor Delisting. Jurnal Keuangan dan Perbankan, 16 (1), 56-65.

Ghozali, Imam. 2013. Aplikasi Analisis Multivariate dengan Program IBM SPSS 21. Cetakan Ketujuh. Semarang: Badan Penerbit Universitas Diponegoro. 
Husein, P.M dan T.G Pambekti.2014. Precision of the Models of Altman, Springate, Zmijewski, and Grover for Predicting the financial distress. Journal of Economic, Business, and Accountancy Ventura. 17(3) : 405-416.

Lukman, M. dan N.Ahmar. 2015. Model Prediksi Kebangkrutan Fullmer H-Score dan Springate: Mana yang lebih kuat?. Seminar Nasional Cendekiawan 2015 STIE Perbanas : 19-29.

Permana, R.K.,Nurmala A.dan Syahril D. 2017. Prediksi Financial Distress pada Perusahaan Manufaktur di Bursa Efek Indonesia. Jurnal Bisnis dan Manajemen. 7(2) : 149-166.

Puspitasari, W.E .2014. Penggunaan Model Zmijewski, Springate,Altman Z-Score dan Grover dalam memprediksi kepailitan pada perusahaan transportasi yang terdaftar di BEI. Jurnal FEB Universitas Dian Nuswantoro.4 (5) : 80-94.

Putra, Ivan G.S dan Rahma S. Analisis Perbandingan Model Zmijewski dan Grover pada Perusahaan Semen di BEI 2008-2014. Jurnal Riset Akuntansi dan Keuangan. JRAK. 4(3). 49-62.

Husein, P, M. \& T.G. Pambekti. (2014). Precision of the models of Altman, Springate, Zmijewski, and Grover for predicting the financial distress. Journal of Economics, Business, and Accountancy Ventura, Vol. 17 (3): 405-416.

Rahayu, dan Putri.2016. Analisis penggunaan metode Springate (S-Score) sebagai prediktor kebangkrutan (Studi pada Perusahaan Textil yang terdaftar di Bursa Efek Indonesia pada Tahun 2011-2013. Jurnal Ekonomi Universitas Muhammadiyah Surakarta. 1(1) : 55-68.

Springate, Gord.L.V .1978. Predicting teh Possibility of Failure in a Canadian Firm.(unpublished MBA Research project).Simon Fraser University.Subramanyam. 2010. Analisis Laporan Keuangan. Ed. 10, Buku 1. Jakarta: Salemba Empat.

Sumantri, dan Teddy Jurnali.2010. manfaat rasio keuangan dalam Memprediksi Kepailitan Bank Nasional. Jurnal Bisnis dan Akuntansi. 12(1).Syahyunan. 2013. Manajemen Keuangan (Perencanaan, Analisis dan Pengendalian Keuangan). USU Press, Medan.

Wulandary, V dan Nur E. 2014. Analisis Perbandingan Model Altman, Springate, Ohlson, Fullmer, CA-Score dan Zmijewski dalam Memprediksi Kesulitan Keuangan (studi empiris pada Perusahaan Food and Beverage yang terdaftar di Bursa Efek Indonesia Periode 2010-2012). JOM FEKOM. 1(2) : 1-18.

Zmijewski, M.E.. 1984. Methodological Issues Relate to the Estimation of Financial of Financial Distress Prediction Models. Journal of Accounting Research. Vol 22: 59-71.

www.idx.go.id

https://www.indonesia-investments.com (diakses pada 25 Juni 2018 pukul 11.50) 